\title{
Ympäristökasvatuksen kehittämisen lähtökohtia liiketalouden koulutuksessa
}

\author{
Liisa Rohweder \\ Kirjoittaja tarkastelee artikkelissa sitä , miten Suomessa \\ toimivat liiketalouden koulutusta tarjoavat ammatti- \\ korkeakoulut edistävät kestävää kehitystä ympäristö- \\ kasvatuksen keinoin ja miten ympäristökasvatusta \\ voitaisiin kehittää tällä koulutusalalla.
}

Kestävän kehityksen nostaminen ihmisen ja luonnon hyvinvoinnin keskeiseksi tavoitteeksi vuonna 1980 julkaistussa World Conservation Strategy:ssä (IUCN 1980) sekä sen jälkeen useissa kansainvälisissä julkaisuissa ja kokouksissa (vrt. Palmer 1998, 3) on vaikuttanut merkittävästi ymmärryksen lisäämiseen siitä, että taloudellinen toiminta ja ympäristönsuojelu tarvitsevat toisiaan eivätkä välttämättä ole ristiriidassa keskenään. Tämän seurauksena on suhtautuminen yrityksiin ympäristöongelmien aiheuttajina alkanut muuttua, koska yrityksillä on nähty olevan yhä suurempi merkitys ympäristöongelmien ratkaisemisessa ja uusien ongelmien ehkäisemisessä. Toisaalta myös yritysten omaehtoinen kiinnostus ympäristöasioihin on kasvanut. Ympäristöjohtamisesta on tullut osa yhä useampien yritysten arkipäivää ja tällöin on myös yritysten osaamistarve liiketoiminnan ja ympäristön kestävän vuorovaikutussuhteen edistämiseksi lisääntynyt (Lovio 1995, 150 \& 1998, 27; Hart 1997, 67; Cramer 1998,170; Joutsenvirta 1998, 49).

Liiketaloudellisessa koulutuksessa toteutettavalla ympäristökasvatuksella on merkittävä vaikutus yritysten suhtautumisessa ympäristöongelmiin, koska tällä alalla koulutetaan niitä tulevaisuuden päättäjiä, jotka voivat omilla asenteillaan ja käy- tännön toimillaan vaikuttaa yritysten kontribuutioon kestävän kehityksen prosessissa (Blackman \& Fleming 1998b, 111; Bragd ym. 1998, 183). Kuitenkin useiden tutkimusten mukaan ei liiketalouden koulutuksessa ole toistaiseksi systemaattisesti mietitty, mitä kestävän kehityksen prosessi edellyttää koulutukselta eikä kouluissa ole edes riittävässä määrin reagoitu yritysten ympäristöosaamistarpeisiin (Barnes \& Ferry 1992, 5; Smith ym. 1994, 476; Ulhoi \& Madsen 1995, 86; Blackman \& Fleming 1998a, b).

Suomessa kestävän kehityksen näkökulman toteutuminen koulutuksessa on pyritty varmistamaan julkisen sektorin toimenpideohjelmilla. Näiden perustana on vuonna 1992 Rio de Janeirossa pidetty YK:n ympäristö ja kehityskonferenssi (UNCED 1992), jossa 172 valtiota allekirjoitti Agenda 21 -toimintaohjelman ilmastonmuutoksen torjumisesta, luonnon monimuotoisuuden suojelemisesta ja aavikoitumisen estämisestä. Edelleen Kioton kokouksessa vuonna 1997 tiukennettiin ilmastosopimusta sekä asetettiin tavoitteeksi, että kaikilla mailla tulisi olla kestävän kehityksen toteuttamisohjelma vuoteen 2002 mennessä. Suomen hallituksen kestävän kehityksen ohjelma, jolla pyritään ekologiseen kestävyyteen ja sitä edistävien taloudellisten, sosiaalisten 
ja kulttuuristen edellytysten luomiseen, toteuttaa tämän tavoitteen (Hallituksen kestävän kehityksen ohjelma 1998). Koska oppilaitokset voivat yhteiskunnassa toimia tehokkaina uusien asioiden eteenpäin viejinä, on hallituksen kestävän kehityksen ohjelmassa asetettu niille tärkeä tehtävä. Hallituksen kestävän kehityksen ohjelman mukaan oppilaitosten perustehtävänä ympäristökasvatuksessa on muuttaa olemassa olevia käsityksiä ja toimia yhteiskunnallisen kehityksen edistäjinä ja osaamisen varmistajina. Lisäksi koulutuksen ja työelämän välinen kytkös on ympäristökasvatuksen suhteen nostettu keskeiseksi kehittämisen kohteeksi.

Myös Suomen hallituksen tekemässä biologista monimuotoisuutta koskevassa kansallisessa toimintaohjelmassa vuosille 1997-2005 on otettu selkeästi kantaa ympäristökasvatuksen tarpeellisuudesta erityisesti korkeakouluissa ja ammatillisella sektorilla. Ohjelmassa sanotaan mm., että tiedekorkeakoulujen ja ammattikorkeakoulujen koulutusohjelmien kehittämisessä tulisi ottaa huomioon biologisen monimuotoisuuden ylläpitäminen ja edistäminen. Lisäksi ohjelman mukaan hallinnon, liiketaloustieteiden, tekniikan, yhteiskuntatieteiden ja oikeustieteen aloilla tulisi kehittää biologisen monimuotoisuuden suojelua, hoitoa ja kestävää käyttöä edistäviä laajapohjaisia opinto-ohjelmia, jotka sitovat yhteen aihepiiriin liittyvät ekologiset, taloudelliset ja yhteiskunnalliset teemat.

Opetushallitus on tuonut kestävän kehityksen käytännön tasolle tekemällä vuonna 1997 omaan toimialueeseensa kuuluvia kouluja varten kestävän kehityksen edistämisohjelman, joka oli alunperin tarkoitus toteuttaa vuoteen 2000 mennessä. Ohjelma perustuu Suomen kestävän kehityksen toimikunnan esittämiin kannanottoihin, ja siinä esitetään myös ne toimenpiteet, joilla kestävä kehitys saadaan aikaan (Hyytiäinen ym. 1999, 9). Vaikka ammattikorkeakoulut eivät kuulu opetushallituksen hallinnonalan piiriin, tukee opetushallitus ammattikorkeakoulujen osallistumista kestävän kehityksen edistämiseen liittyvään koulutukseen.

Artikkelissani analysoin, miten liiketalouden

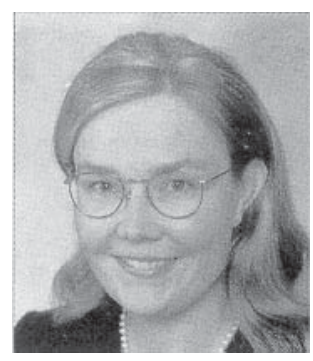

\section{Liisa Rohweder}

koulutusta tarjoavat ammattikorkeakoulut ovat ottaneet huomioon kestävän kehityksen ympäristökasvatuksen keinoin sekä nostan esille ympäristökasvatuksen opetussuunnitelmateoreettisia kehittämisen lähtökohtia ja esteitä kyseisessä koulutuskontekstissa. Teoreettisessa mielessä kiinnitän artikkelini ympäristökasvatuksen tavoitteisiin ja oppimiskäsitykseen sekä Lehrplan ja Curriculum -ajattelun väliseen opetussuunnitelmateoreettiseen keskusteluun.

Ympäristökasvatuksen tutkimus ja siihen liittyvä opetussuunnitelmaan ja oppimiskäsitykseen liittyvä tutkimus on viime vuosina jatkuvasti lisääntynyt. Sen sijaan ympäristökasvatuksen tutkimus liiketalouden kontekstissa ei ole herättänyt laajaa tutkimuksellista mielenkiintoa. Tällä artikkelilla on siten merkitystä teoreettisen ja käytännön ymmärryksen lisäämisessä siitä, miten ympäristökasvatusta tulisi liiketalouden koulutuksessa toteuttaa ja miten vallitsevaa tilannetta voitaisiin kehittää.

\section{AINEISTO JA SEN ANALYYSI}

Tutkimuksessa käyttämäni empiirisen aineiston keräsin Suomessa vuonna 1999 vakinaisena toimivista ammattikorkeakouluista, joissa oli liiketalouden koulutusta. Tällaisia kouluja oli vuonna 1999 yhteensä 22. Aineistona käytin koulujen vuoden 1999-2000 opinto-oppaita sekä vuosina 1999 ja 2000 tekemiäni haastatteluja.

Opinto-oppaiden kurssikuvauksia analysoin luokittelemalla ympäristöasioihin liittyviä kursseja erilaisiin ryhmiin. Lisäksi etsin opinto-oppaista viitteitä ympäristökasvatuksen integroivasta toteutuksesta. 
Teemahaastatteluiden avulla sain käsityksen ympäristökasvatuksesta osana opetussuunnitelmaprosessia. Kustakin koulusta haastattelin opetussuunnitelmaprosessissa mukana olleita liiketalouden koulutusohjelmajohtajia $(n=22)$ sekä ympäristökasvatuksen opettajia ( $\mathrm{n}=9$ ). Koulutusohjelmajohtajat auttoivat haastateltavien opettajien nimeämisessä. Opettajien valintakriteerinä oli se, että heidän tuli olla liiketalouden koulutusohjelmassa vakinaisessa työsuhteessa ja heidän päävastuualueenaan tuli olla ympäristöasioihin liittyvät kurssit. Kahdessatoista koulussa ei liiketalouden koulutusohjelmassa ollut omaa ympäristöasioihin perehtynyttä opettajaa, vaan opettaja ostettiin tarvittaessa ulkoisena palveluna koulun jostain muusta koulutusohjelmasta tai kokonaan kouluyhteisön ulkopuolelta. Näistä opettajista haastattelin vain yhtä. Päädyin tähän ratkaisuun kyseisen opettajan ja koulutusohjelmajohtajien haastatteluiden jälkeen. He toivat selkeästi esille sen seikan, että muiden koulutusohjelmien opettajat tarjosivat ympäristöasioihin liittyviä kursseja oman koulutusohjelmansa lähtökohdista. Myöskään koulun ulkopuoliset, sivutoimiset opettajat, eivät olleet mukana liiketalouden koulutusohjelman opetussuunnitelmatyöskentelyssä.

Käyttämäni haastattelurunko liittyi laajempaan tutkimukseen, jossa kehitin ympäristökasvatuksen opetussuunnitelmateoreettisen mallin liiketalouden koulutukseen (Rohweder 2001). Varsinainen haastattelurunko oli vain keskustelun pohja. Haastateltavat saivat vapaasti johdatella keskustelua aihepiiristä toiseen. Tämä menettelytapa mahdollisti tässä artikkelissa esiin nostettavien ympäristökasvatuksen kehittämisajatusten syntymisen. Tarkoituksenani oli löytää kehittämislähtökohtia tutkittavien näkökulmasta, eikä omasta näkökulmastani, ja ymmärtää ympäristökasvatusta osana opetussuunnitelmaprosessia sellaisena, kuin se aidoimmillaan on (vrt. Goez \& LeCompte 1984, 10; Sherman \& Webb 1988, 124). En myöskään tutkinut haastateltuja yksilöinä, vaan saman kulttuurin edustajina (vrt. Alasuutari 1988, 65). Näin ollen pyrkimyksenäni oli tulkita haastatteluja ja yhdistää samansisältöisiksi tulkitsemani havainnot kategorioiksi. Tässä artikkelissa esittämäni ympäristökasvatuksen ke- hittämisajatukset nousivat siis induktiivisesti muodostamistani tulkinnallisista yleistyksistä.

Tutkimukseni luotettavuutta arvioitaessa on ennen muuta kyse tulkintojen validiteetista. Validiteetin näkökulmasta keskeiseksi nousevat ensinnäkin mahdolliset käsitteelliset epäselvyydet (vrt. Syrjälä ym. 1994, 100). Pyrin poistamaan niitä tekemällä kaksi esihaastattelua. Esihaastattelemani esimies ja opettaja olivat minulle entuudestaan tuttuja, joten uskoin saavani heiltä rehellistä palautetta käyttämästäni haastattelurungosta. Lisäksi oletan, että käsitteellisiä epäselvyyksiä syntyi mahdollisimman vähän, koska itsekin työskentelen opettajana ja näin ollen käsitemaailmani on mahdollisimman samankaltainen haastateltavien käsitemaailman kanssa. Validiteettiin vaikuttaa myös se, miten suoritin haastattelut. Tutkijan pitäisi Ballin (1984) mukaan olla haastattelutilanteessa mahdollisimman epäformaali ja luoda haastattelutilanteesta sellainen, ettei haastateltava tunne olevansa ainoastaan tutkimuksen kohde, vaan että hän tutkijan kanssa yhdessä kehittää tutkittavaa ilmiötä. Mielestäni onnistuin Ballin esittämissä vaatimuksissa, koska haastattelut olivat enemmänkin keskustelutilanteita, joissa kollegan roolissa kehitin yhdessä haastateltavien kanssa kyseistä opetusalaa.

Tutkimuksen validiteettia eniten heikentävänä tekijänä pidän sitä Tilburyn ja Walfordin (1996, 54) esittämää tulkinnallisen tutkimuksen vahvuutta, jonka mukaan tutkija on kontekstissa mukana ja luottaa omaan tulkintaansa aineiston keräämisessä ja analysoimisessa. Itselleni on ympäristöalan opettajana muodostunut luonnollisesti ennakkokäsityksiä tutkittavasta aiheesta. Keskeiseksi muodostuu näin ollen se, miten kykenin sulkemaan omat ennakkokäsitykseni analyysin ulkopuolelle. Tähän validiteettiin vaikuttavaan tekijään pyrin vaikuttamaan siten, että esitän tutkimuksessani mahdollisimman paljon haastatteluissa nauhoittamiani tekstinäytteitä.

\section{YMPÄRISTÖKASVATUS LIIKE- TALOUDEN KOULUTUKSESSA}

Ympäristökasvatuksen näkökulmasta on positiivista, että liiketalouden koulutuksessa ammatti- 
korkeakoulutasolla lähes kaikissa kouluissa on tarjolla yksi tai useampi ympäristöasioihin liittyvä kurssi ja, että kaikki haastatellut yhtä koulutusohjelmajohtajaa lukuun ottamatta olivat sitä mieltä, että ympäristöasioiden merkitys kasvaa liiketalouden koulutuksessa. Haastateltavat perustelivat kantaansa sillä, että samalla kun kestävän kehityksen painoarvo kasvaa yhteiskunnassa, kasvaa myös yritysten ympäristöasioiden hallintaan liittyvä osaamistarve.

"Sen merkitys on ehdottomasti vielä muuttumassa. Pakko. Sanotaan, että ammattikorkeakouluun tulee varmaan pikkuhiljaa pakolliseksi tätä ympäristöopetusta enemmän kuin sitä tällä hetkellä on.”

Tutkituista 22 liiketalouden koulutusta tarjoavasta ammattikorkeakoulusta neljässä ei ollut ympäristökasvatukseen liittyviä kursseja lainkaan. 11 koulussa oli kaikille liiketalouden opiskelijoille tarkoitettuja ympäristöasioihin liittyviä pakollisia kursseja. Lisäksi kuudessa koulussa oli ympäristökasvatukseen liittyviä pakollisia opintoja tietyn suuntautumisvaihtoehdon valinneille opiskelijoille. Ympäristökasvatukseen liittyviä vapaaehtoisia tai valinnaisia kursseja oli yhteensä 15 koulussa. Haastatteluiden perusteella näitä kursseja toteutettiin kuitenkin hyvin satunnaisesti ja joissakin tapauksissa niitä ei ollut toteutettu koskaan. Yhdessä koulussa oli tarjolla liiketalouden suuntautumisvaihtoehtona ympäristöjohtamisen koulutusohjelma. (Liitteeseen 1 nettisivulle www.kvs.fi $>$ Aikuiskasvatusjulkaisut $>$ Aikuiskasvatus $>$ Tärppejä nettilukijalle on koottu yhteenveto liiketalouden opiskelijoille tarjolla olevista ympäristökursseista.)

Liiketalouden opiskelijoiden pakolliset ympäristökurssit toteutettiin joko liiketalouden koulutusohjelman vakinaisten opettajien tai muiden koulutusohjelmien opettajien/ sivutoimisten opettajien toimesta. 10:ssä liiketalouden koulutusta tarjoavasta 22:sta ammattikorkeakoulusta oli oma ympäristökasvatuksesta vastaava opettaja.

Opinto-oppaiden kurssitarjontaan perustuvan analyysin mukaan ympäristökasvatuksen näkökulmaa oli integroituna 12 koulussa (Liite 2 Ai- kuiskasvatuksen nettisivuilla). Esimerkkejä tällaisista kursseista ovat "Markkinoinnin kilpailukeinot" ja "Yksilö muuttuvassa yhteiskunnassa."

\section{Markkinoinnin kilpailukeinot:}

"Opiskelija tuntee kilpailukeinot, niiden käyttöön liittyvän lainsäädännön sekä ympäristövaikutukset. Opiskelija osaa soveltaa kilpailukeinoja erilaisissa kilpailutilanteissa."

\section{Yksilö muuttuvassa yhteiskunnassa:}

"Opiskelija laajentaa näkemystään yhteiskunnasta ja sen tulevavaisuuden visioista, yhteiskunnan eri osa-alueista sekä yksilöstä osana yhteiskuntaa. Opiskelija oppii tarkastelemaan oman ammattialansa suhdetta yhteiskuntaan ja sen eri ulottuvuuksiin. Opiskelijalle syntyy ymmärrys taloudellisten, sosiaalisten, kulttuuristen ja ekologisten tekijöiden vaikutuksesta yhteiskunnassa ja omalla ammattialallaan."

Kaikki haastateltavat pitivät integrointia hyvänä lähtökohtana ympäristökasvatuksen toteuttamiseksi. Tämän eteen ei organisaatiotasolla kuitenkaan ollut tehty minkäänlaisia toimenpiteitä.
"Meilläkin toiset sanoo, että meillä ei tarvita enää yhtään erillistä ympäristöalan kurssia, vaan ne asiat kuuluu toisten aineiden sisään. Niiden toisten aineiden sisällä se kyllä lisään- tyy."
"Integroitunahan sen pitäisi olla, mutta tää integrointi on sellasta, että se riippuu kysei- sen opettajan omista valmiuksista. Ei täällä (opinto-opas) ainakaan otsikkotasolla ole in- tegrointia. Sitä mä en osaa sanoa, että mi- ten joku markkinoinnin opettaja ottaa nää asiat huomioon."

Vaikka ympäristönäkökulmaa pidettiin tärkeänä liiketalouden koulutuksessa, ja sitä on lähes jokaisessa koulussa, nousi haastatteluihin ja opinto-oppaisiin perustuvan analyysin perusteella kuitenkin esille selkeitä ympäristökasvatuksen kehittämisajatuksia. Nämä liittyivät ympäristökasvatuksen tavoitteisiin, oppimiskäsitykseen ja niitä tukevaan integroivaan toteutukseen opetussuunnitelmassa. 
KOHTI TAVOITTEITA INTEGROIVALLA LÄHESTYMISTAVALLA

Opetussuunnitelmakeskustelu voidaan kiteyttää Lehrplan ja Curriculum-ajattelun väliseen dialogiin. Saksalaisen Herbartin (1776-1841) alkujaan kehittämässä Lehrplan-ajattelussa korostuvat opetussuunnitelman hallinnolliset ratkaisut. Opetussuunnitelmatyöskentelyssä huomio kiinnittyy näin ollen koulutuksen päämääriin, oppiaineiden valintaan, tuntijakoon, oppiaineiden tavoitteisiin, arviointiin ja resurssointiin (Malinen 1985, 17; Rauste-von Wright 1994, 118). Suomessa luovuttiin virallisesti 1990-luvulla Lehrplan-tyyppisestä valtakunnallisesta suunnittelusta ja siirryttiin Deweyn (1859-1952) kehittämän Curriculum-ajattelun mukaiseen opetussuunnitelmien paikalliseen, koulukohtaiseen suunnitteluun. Tämän ajateltiin mahdollistavan entistä nopeamman reagoinnin toimintaympäristön muuttuviin tarpeisiin. Kun Lehrplan ajattelussa keskeistä on opetukseen liittyvä hallinnointi, perustuu Curriculum-ajattelu puolestaan oppilaan kokonaiskehitykseen ja pedagogisiin ratkaisuihin. Curriculum-käsitteestä on myös peräisin tutkijoiden viimeaikainen pyrkimys liittää opetussuunnitelma oppimiseen ja avoimeen toimintaympäristökontekstiin. Esimerkiksi Ropo (1994, 105) on määritellyt ammatilliseen kontekstiin liittyvän opetussuunnitelman Curriculum -lähtöisesti siten, että se on ikään kuin oppimisen pienoismaailma, jossa vaikuttavat oppimisprosessit muuttavat, opettavat ja kasvattavat yksilöä. Tavoitteena tulisi olla oppimista elämänasenteena ja elämänhallintana kehittävä oppimisympäristö. Von Wrightin $(1993,30)$ Curriculum-ajatteluun liittyy lisäksi pyrkimys luoda oppimisympäristö, joka tarjoaa oppilaalle ongelmia, keinoja näiden ratkaisemiseksi, ohjausta ja tukea. Taustalla on tällöin oletus, että ihminen pyrkii muuttamaan maailmaa ja etsimään syitä ja selityksiä.

Oppimiskäsitystä on 1990-luvulta lähtien nostettu Curriculum-ajattelun myötä yhä enemmän opetussuunnitelmatutkimuksen yhteyteen (vrt. Linde 1993, 34; Kauppi 1998, 44). Tällöin oppimista ei pidetä ainoastaan opetussuunnitelmaa seuraavana toteuttamisvaiheena, vaan sil- lä nähdään olevan merkitystä myös itse opetussuunnitelman laadintaan. Tutkimuksen piirissä on sekä ympäristökasvatuksen oppimiskäsitys, että myös oppimiskäsitys yleisellä tasolla muuttunut parin viimeisen vuosikymmenen aikana. Tätä kuvaa siirtymä objektivistisesta behavioristisesta käsityksestä kohti konstruktivistista ja kognitiiviseen psykologiaan ja toimintateoreettiseen käsitykseen perustuvaa oppimisen mallia (esim. Rauste-von Wright 1994, 117 \& 123; Tella 1994, 26; Autio ym. 1998, 303). Oppiminen nähdään konstruktiivisena prosessina, jossa oppija rakentaa henkilökohtaisen tulkinnan kokemuksestaan. Oppiminen on lisäksi sidoksissa siihen toimintaan, kontekstiin ja kulttuuriin (= oppimisympäristö), jossa tietoa opitaan ja käytetään (Rauste-von Wright 1994, 131; Tella 1994, 28; Ballantyne \& Packer 1996, 27). Konstruktivismissa oppimisen painopiste on aktiivisen, toimivan subjektin tuottamisessa.

Lehrplan-lähtöinen opetussuunnitelmatyöskentely ei tue ympäristökasvatuksen tavoitteita, koska ympäristökasvatuksessa ei ole kyse ainoastaan erillisistä kursseista, vaan Curriculum-ajattelun mukaisesta oppimisprosessista ja kokonaisvaltaisen ajattelutavan kehittymisestä. Käsitteenä ympäristökasvatus on laaja ja monitieteinen kokonaisuus, joka liittyy ihmisen ja hänen luontosuhteensa dynamiikan kokonaisvaltaiseen tarkasteluun, tämän vuorovaikutussuhteen tiedostamiseen ja tukemiseen. Ympäristökasvatuksen keinoin pyritään lisäämään tietoa ja ymmärrystä, vaikuttamaan arvoihin ja asenteisiin sekä lisäämään taitoja ympäristöongelmiin vaikuttamiseksi. Sen tulisi lisäksi olla jatkuva prosessi, jossa yksilö alkaa pohtia omaa toimintaansa sekä sen seurauksia ja motivoituu työskentelemään ympäristöongelmien ratkaisemiseksi (vrt. Stap 1969, 30; Greenall 1986, 9 Mrazek 1993, 11; Ojanen \& Rikkinen 1995, 12).

Ympäristökasvatuksen tutkimuksessa puhutaan holistisesta, kokonaisvaltaisesta lähestymistavasta oppimiseen. Oppimisprosessissa tulisi tiedot, taidot ja asenteet kytkeä toisiinsa ympäristömyönteisen toiminnan aikaansaamiseksi (Palmer 1998, 269). Mielestäni myös liiketalouden koulutuskontekstissa ympäristöasioihin liittyvän opetuk- 
sen tulisi nojautua ympäristökasvatuksen yleisiin tavoitteisiin. Näin ollen määrittelen liiketalouden koulutuksen yhteydessä ympäristökasvatuksen tavoitteeksi sen, että opiskelijalle muodostuu halu ja kyky omalta osaltaan vaikuttaa tulevassa työyhteisössään ympäristötietoisen organisaation aikaansaamiseen ja siten luonnon talouden ja ihmisen talouden välisen kestävän vuorovaikutuksen edistämiseen. Ympäristökasvatuksen tavoitteena liiketalouden koulutuksessa on oppijaan pitkäaikaisesti ja kokonaisvaltaisesti vaikuttava asenteisiin ja arvoihin sidoksissa oleva muutos, jonka seurauksena oppija haluaa aikaansaada muutoksia organisatorisessa ajattelussa ja organisaation käytännön toimintatavoissa (vrt. Rohweder 2001, 28). Käytännössä tämä haastava tavoite voidaan saavuttaa sisällyttämällä ympäristökasvatuksen tavoitteiden mukaista ajattelutapaa integroidusti eri ammattiaineiden kursseihin. Tämä mahdollistuu Curriculum -lähtöisellä opetussuunnitelmatyöskentelyllä, jolloin keskeiseen asemaan nousevat kokonaisvaltaisten oppimisprosessien ja oppimistavoitteiden hahmottaminen, eivät erillisten kurssien pirstaleiset tavoitteet.

Myös Sinding ym. (1997,9), Blackman \& Fleming (1998a, 88), Hynninen (1998, 289), Lovio (Sipilä 1998, 18), Rajanen (1998, 33) ja Beringer ym. (1999, 355) ovat esittäneet ajatusta kokonaisvaltaisesta ja integroidusta ympäristökasvatuksesta liiketalouden korkeakoulukontekstissa. Integroiva toteutus liiketalouden koulutuksessa tukee ympäristöongelmien ratkaisemisen kannalta keskeistä ajatusta siitä, että niitä ei tulisi lähestyä yritysten päätöksenteossa erillisinä ongelmina, vaan osana muuta yhteiskunnallista ja yritysten päätöksentekoa (vrt. Turtiainen 19991; Beringer ym. 1999, 334; Raumolin 2000, 51). Beringerin ym. (1999) mukaan integrointi on lisäksi tehokas keino vaikuttaa opiskelijoiden maailmankatsomukseen, jota hänen mukaansa luonnehtii lokeroituminen ja pirstaleisuus. Useat tutkimukset ovat osoittaneet, että opiskelijat eivät osaa soveltaa irrallisina opittuja tietoja ja taitoja todellisissa ongelmatilanteissa koulun ulkopuolella, vaan ne jäävät ns. tehottomiksi, passiivisiksi tiedoiksi (Järvelä 1997, 85). Ulhoi \& Madsen $(1995,91)$ ovat esittäneet mallin siitä, miten ympäristökasvatus integroituu osaksi liiketalouden koulutusta. Integorointi toteutuu Ulhoin \& Madsenin mukaan vaiheittain siten, että koulujen kurssitarjontaan tulee ensin muutamia satunnaisia ympäristökasvatukseen liittyviä kursseja. Tämän jälkeen, samalla kun ympäristökasvatuksen arvostus kasvaa, ympäristökasvatukseen liittyvät kurssit tulevat säännöllisesti toistuviksi ja niiden määrä lisääntyy. Lopuksi erilliset ympäristökasvatukseen liittyvät kurssit korvataan muiden aineiden sisään integroiduilla toteutuksilla. Jotta integrointi voisi toteutua, tulisi opettajien pitää ympäristökasvatusta tärkeänä ja heillä tulisi olla riittävät valmiudet integroinnin toteuttamiseen. Koska Suomessa ympäristökasvatuksen merkityksen uskotaan kasvavan ja lähes kaikissa kouluissa on yksi tai useampi säännöllisesti toistuva ympäristökasvatukseen liittyvä kurssi, on integrointiprosessi Ulhoin \& Madsenin mallin perusteella lähtenyt käyntiin. Varsinaista ympäristökasvatuksen suunnitelmallista integroitumista opetussuunnitelmaan ei kuitenkaan vielä ole tapahtunut. Tähän liittyvään ongelmakokonaisuuteen palaan seuraavassa kappaleessa.

Ulhoin ja Madsenin mallissa on huomioimisen arvoista se, että siinä korostuu vaiheittain etenevä integrointi. Tämä takaa sen, että integrointi muiden aineiden sisään ei tarkoita sitä, että ympäristökasvatuksen ulottuvuus unohtuu vähitellen opetussuunnitelmasta. Myös Palmer (1998, 273) on esittänyt, miten ympäristökasvatuksen ulottuvuus voidaan varmistaa integrointiprosessin yhteydessä. Hänen mukaansa koulussa on ensinnäkin määriteltävä organisaatiotasolla ympäristökasvatuksen tavoitteet, päämäärät, toimenpiteet, sisällöt, menetelmät ja resurssit. Toiseksi, koulussa on oltava ympäristökasvatuksesta vastaava yhteyshenkilö. Kolmanneksi, koulussa tulee olla toimenpideohjelma ympäristökasvatuksen toteutuksen tarkastamista varten. Neljänneksi, opettajien jatkuvan kouluttautumisen mahdollisuus on turvattava. Palmerin esittämä lista ympäristökasvatuksen varmistamiseksi ei kuitenkaan oman empiirisen aineistoni perusteella toteudu toistaiseksi Suomessa. Ensiksikin, ympäristökasvatuksen tavoitteisiin ja oppimiskäsitykseen liittyvä opetussuunnitelmatyöskentely ei ole 
systemaattisesta. Toiseksi, vain 10:ssä liiketalouden yksikössä 22:sta on ympäristökasvatuksesta vastaavaa yhteyshenkilö. Kolmanneksi, kouluissa ei ole toimenpideohjelmaa ympäristökasvatuksen toteutuksen tarkastusta varten. Lisäksi opettajien ympäristökasvatukseen liittyvä koulutus ei ole organisoitua.

\section{LEHRPLAN-AJATTELU INTEGROINNIN ESTEENÄ}

Tutkimukseni paljasti kaksi ympäristökasvatuksen integrointiprosessin etenemisen selkeää estettä, jotka ovat "opettajakeskeisyys" ja "reviiriajattelu". Nämä esteet vaikuttavat myös siihen, miksi integrointi ei Suomessa voi edetä edellä esitettyjen Ulhoin \& Madsenin ja Palmerin ajatusten mukaisesti. Opetussuunnitelmatutkimuksen kannalta merkittävää on se, että molemmat identifioidut esteet liittyvät "pannaan" julistetun Lehrplan-ideologian mukaiseen opetussuunnitelmatyöskentelyyn.

\section{Opettajakeskeisyys}

Ympäristökasvatuksen ottaminen mukaan liiketalouden koulutusohjelman opetussuunnitelmaprosessiin tai sen siitä poisjättäminen riippui yksittäisten opettajien aktiivisuudesta ja heidän henkilökohtaisesta työpanoksestaan. Jos liiketalouden koulutusohjelmassa ei ollut ympäristökasvatuksen puolesta puhuvaa opettajaa, ei ympäristökasvatuksen näkökulmaa myöskään otettu huomioon opetussuunnitelmaprosessissa. Keskeisenä esteenä ympäristökasvatuksen kehittämisessä on siis se, että vain ympäristökasvatukseen vihkiytyneet opettajat vievät tätä asiaa eteenpäin. Yhtenä selityksenä tähän on koko opettajakuntaan kohdistuva koulutustarve. Opettajat eivät ole tietoisia siitä, miten ympäristöasiat tulisi integroida opetukseen. Toisaalta heitä ei ole myöskään edellytetty näin tekemään.

" Tää on hirveen pitkälle mun henkilökohtainen juttu."

"No se ympäristökurssi lähti liikkeelle, voi olla että sen vuoksi, että mie olin kovaääninen... kyllä se on opettajakeskeistä..."

"Mutta jos meillä ei olis ollut henkilöä, joka olis ollu niin innokas näissä, niin ei me oltas osattu nostaa kissaa pöydälle.”

"Jos koulussa olis opettaja, joka nostais ympäristökurssin tarvetta esille, niin se saattais toteutuakin. Välttämättä tällä tavalla, kun meidän pakollinen kurssi, niin kun opettaja tulee toiselta alalta, niin opiskelijat ei välttämättä näe sitä niin tärkeäksi ja omaksi. Siihen pitäis saada joku, joka nivois sen tähän kaupalliseen ympäristöön. Meillä ei nyt ole semmosta opettajaa, joka olis siihen perehtyny. Kyllähän siihen pitäis jonkun ihmisen innostua ja lähteä siihen."

"Tota kaupan ja hallinnon puolella, niin meillä on ollu näitä kaupallisten aineiden opettajia, laskentatoimen ja markkinoinnin ja niin edelleen ja kun heillä ei ole ympäristönsuojelun näkemystä, niin ympäristönsuojeluasiat jäi pois."

Ajatusta ympäristökasvatuksen opettajakeskeisyydestä ja systemaattisen suunnitelmallisuuden puutteellisuudesta vahvistaa vielä se, että kahdessa koulussa ympäristökasvatuksen ulottuvuus oli poistettu opetussuunnitelmasta sen vuoksi, että asiaa esiinnostava opettaja ei ollut enää työsuhteessa ammattikorkeakouluun.

"Meillä oli vapaasti valittavana ainakin X:ssä ympäristötietous, mutta kun opettaja lähti pois, niin se tiputettiin pois."

"Meillä oli ympäristötaloustiede ennen tarjolla, mutta se poistettiin, kun ei ole enää opettajaa, eikä kukaan halua ottaa sitä. Siinä ei ollut sisällöllisesti ongelmaa, mutta se oli ammattiopinnoissa pakollinen, mutta se siis poistettiin kun ei tiedetty, kuka sen hoitais."

Mikäli liiketalouden koulutuksessa ei ollut omaa ympäristökasvatuksen opettajaa, saattoi opiskelijoiden opintoihin silti sisältyä ympäristökasvatuksen opintoja (36\% kouluista). Tällaisissa tapauksissa aloite ympäristökasvatukseen liittyvistä kursseista oli tullut monialaisen ammattikorkeakoulun luonnonvara-alan, tekniikan tai sosiaali- ja terveysalan koulutusohjelmasta. Ympäristökasvatukseen liittyvät kurssit ostettiin näistä koulutusohjelmista ulkoisina palveluina eikä sitä, oliko niiden sisältö sellaisenaan paras mahdolli- 
nen kaupallisen alan opiskelijoiden ammatillisen kehittymisen näkökulmasta ollut alunperin kyseenalaistettu. Myös tämä ilmensi sitä, että kouluissa ei ollut tarpeeksi osaamista miettiä ympäristökasvatuksen sisältöä liiketalouden koulutuksen näkökulmasta.

"Mut et meillä on semmonen pakollinen paketti, joka tulee kaikille koko amkossa (= ammattikorkeakoulussa), mut sit näissä meiän talouden ja hallinnon omissa opinnoissa ei sitten ole mitään pakollista..."

"Meillä sanotaan näin, että olisko me huomattu ottaa sitä sinne itse, mutta mun mielestä tää sosiaali- ja terveysala ja tekninen ala, joissa sitä on ollu enempi, niin sanoi, että tää olis sellainen, joka sopis kaikille pakolliseks."

"Ehkä tuolla tekniikan puolella on pitemmät perinteet. Siellä on pidemmän aikaa ollu ympäristöasiat osana koulutusta."

"Ympäristönäkökulmaa otettiin, koska se tuli sieltä terveydenhuollon puolelta."

"Tekniikassahan sitä on tällä hetkellä yleensä Suomessa. Kaupallisella alallahan tämä on vasta nyt alkamassa. Teknisellä puolella on ollut lainsäädäntö, joka on määritelly päästöjä.”

Esimerkiksi Wahlström Suomessa (1993, 363) ja Smith ym. Isossa Britanniassa $(1994,458)$ ovat päätyneet siihen, että yhtenä ympäristökasvatuksen toteuttamisen esteenä liiketalouden koulutuksessa on yleinen kiinnostuksen puute ja että ympäristökasvatuksen näkökulmaa ei pidetä koulutusalalla tärkeänä. Becker USA:ssa $(1997,6)$ on puolestaan nostanut esille ympäristökasvatuksen toteuttamisen esteenä korkeakouluille tyypillisen lokeroituneisuuden, jolloin eri alojen opettajat eivät keskustele keskenään.

Oman empiirisen aineistoni valossa näyttää siltä, että opettajat ja koulutusohjelmajohtajat pitävät ympäristökasvatusta tärkeänä näkökulmana ja toteutuksen esteenä on lähinnä tietotaidon puute. Myös Ulhoin \& Madsenin $(1995,86)$ EU:ssa tekemän empiirisen tutkimuksen mukaan liiketaloudellisessa koulutuksessa toteutettavan ympäristökasvatuksen yhtenä selkeänä esteenä on opettajakunnan ympäristöasioihin liittyvän kou- lutuksen vähäisyys. Samoin Blackmanin \& Flemingin (1998a, 83) Isossa-Britanniassa tekemän tutkimuksen mukaan vain kouluttamalla kaikkia opettajia ja sitä kautta sisällyttämällä ympäristökasvatus kokonaisvaltaisesti opetussuunnitelmaan voi olla mahdollista, että ympäristöasiat myöhemmin siirtyvät myöskin yritysten päätöksentekoprosessiin.

\section{Reviiriajattelu}

Ympäristökasvatuksen toiseksi selkeäksi toteuttamisen esteeksi identifioin tuntijakoon perustuvan reviiriajattelun.

”Näistä tunneista taistellaan kovasti. No meillä varsinkin alkuvaiheessa vaikutti paljon ihan opettajat, heidän virat ja heidän työllistämisensä."

"Se jää siihen, että kun meillä on 40 ov niitä pakollisia perusopintoja niin se on semmosta kissan hännän vetoa se opetussuunnitelmatyö ettei ole tosikaan. Kun jokainen perustelee, miksi juuri hänen aineensa on tärkeää. Jokaisella on intressinsä opettaa omia kursseja, ja jos kukaan ei nosta ympäristökasvatusta esille, niin se jää sitten pois."

"Kyllä jos ajattelee tätä koulua, niinku vakinaistamisvaiheessa, niin se tilanne oli tietysti se, että asioiden poisjääminen liittyi henkilökohtaisiin asioihin, että se, joka ei ollu valvomassa omien asioidensa etuja, niin pudotettiin pois."

"Ihan väistämättä tullaan siihen, että opettajien omat osaamisalueet ja kiinnostuksen kohteet ovat ohjanneet sitä, että tätä pitää olla, eli se on sellaista, että jos sanon rehellisesti, niin edelleen siinä ollaan tuotantopainotteisia... Me tiedetään mun mielestä kaikissa ammattikorkeakouluissa tällä hetkellä aika tarkkaan, mitä maailma on, mutta tuotantolähtöinen ajattelu on kuitenkin vallalla, että kun mä osaan tätä, niin mä tarjoon tätä. Mä en usko, että sitä maailmaa olis kuunneltu niin kauheesti, että nyt tällaista tarvitaan (ympäristökasvatusta). Mä uskallan väittää, että kovin moni ammattikorkeakoulu ei ole palkannut asiantuntijaa siihen, että me ruvetaan nyt ottamaan tätä haastetta vastaan.” 
Se, että koko koulutusorganisaatio sisäistäisi ympäristökasvatuksen merkityksen opetussuunnitelmassa, näyttää edellyttävän eri aihepiirien opettajien kouluttautumisen lisäksi koko korkeakoulukulttuurin muuttamista oppimiskeskeisempään suuntaan. Myös muissa tutkimuksissa on erääksi ympäristökasvatuksen toteuttamisen esteeksi identifioitu Lehrplan -ajattelusta lähtöisin oleva reviiriajattelu sekä siihen liittyvä valtataistelu tunneista (vrt. Ulhoi \& Madsen 1995, 89; Wahlström 1993, 363).

\section{PÄÄTELMÄT}

Lähtökohtaisesti ympäristökasvatuksen tilanne on hyvä, koska lähes jokaisessa ammattikorkeakoulussa on ympäristökasvatusta ja ympäristökasvatuksen merkityksen uskotaan lisääntyvän.

Ympäristökasvatuksen tavoitteiden kannalta ei kuitenkaan riitä, että ympäristöasioihin liittyvät kurssit määrätään pakollisiksi, vaan liiketaloudellisen toiminnan vaikutuksia luontoon sekä muuhun yhteiskuntaan tulisi miettiä asiayhteyksittäin. Ympäristökasvatuksen tavoitteiden toteutumisen näkökulmasta kouluissa olisi syytä pohtia ympäristökasvatuksen toteuttamista kokonaisvaltaisesti, jotta se saataisiin integroitua koko opetussuunnitelman läpikäyväksi ajatukseksi. Integroiva lähestymistapa edellyttää kuitenkin yhteisen tahto- ja tavoitetilan saavuttamista, se ei onnistu yksittäisten aiheesta innostuneiden opettajien voimin. Käytännön työvälineen tähän tarjoaa esimerkiksi ympäristönhallintajärjestelmän (ISO 14001) pohjalta kehitetyt kestävän kehityksen ohjelmat, jotka liittyvät koko koulutusorganisaation systemaattiseen kestävän kehityksen mukaiseen kehittämiseen, eivät ainoastaan ympäristökasvatuksen integroimiseen opetussuunnitelmaan (kts. esim. Hyytiäinen ym. 1999).

Integroivaan lähestymistapaan liittyy myös muutos koulutuksen kokonaisvaltaisista tavoitteista lähtevään oppimiskeskeisempään opetussuunnitelmaan, joka samalla liittyy koulukulttuurin muutokseen. Empiirinen aineistoni paljasti, että vaikka tutkimuksen piirissä Lehrplan-ajattelusta opetussuunnitelman kehyksenä on jo luovuttu, näyttää siirtymä Curriculum-lähtöiseen opetus- suunnitelmaan olevan ammattikorkeakouluissa vielä kesken.

Koulukulttuurin muuttumisen ensimmäinen edellytys on sen epäkohtien tiedostaminen ja muutostarpeen hyväksyminen. Joka tapauksessa kyse on pitkäaikaisesta opetussuunnitelmatyöskentelyyn liittyvästä muutosprosessista.

Käytännössä koulukulttuurin muutos voisi lähteä liikkeelle arvioimalla perinteinen kursseihin perustuva opetussuunnitelma uudelleen. Yhtenä vaihtoehtona voidaan mainita Curriculumajattelua tukeva ongelmaperustaiseen oppimiseen perustuva opetussuunnitelmallinen lähestymistapa (esim. Lonka \& Hakkarainen 2000 ja Hakkarainen ym. 1999). Koska ongelmaperustaisen opetussuunnitelman laadinnassa ei keskeistä ole tuntijako ja eri kurssien arvottaminen opintoviikkojen mukaan, ei reviiriajattelu ja valtataistelu tunneista ole enää keskeisellä sijalla. Huomio kiinnittyy sen sijaan opettajien kollektiivisen asiantuntijuuden perusteella laadittuihin koulutuksen yhteisiin oppimistavoitteisiin ja opiskelijoiden oppimisprosessin toteuttamiseen. Ongelmaperustaiseen opetussuunnitelmaan liittyviä kehityshankkeita on meneillään ainakin Satakunnan ammattikorkeakoulussa ja Helsingin liiketalouden ammattikorkeakoulussa, joissa molemmissa tietyn liiketalouden suuntautumisvaihtoehdon valinneet tradenomiopiskelijat opiskelevat Curriculum-ajatteluun tukeutuvan ongelmalähtöisen opetussuunnitelman mukaisesti.

Ympäristökasvatuksen integroiva toteutustapa liiketalouden koulutusta tarjoavissa ammattikorkeakouluissa antaa haasteita sekä kauppatieteelliselle korkeakoulutason opetukselle, että ammatilliselle opettajankoulutukselle, joissa opettajat hankkivat ammatillisen pätevyytensä. Tavoitteellista olisi, että tulevat liiketalouden opettajat opiskelisivat jo perustutkintovaiheessa, miten ympäristöasioita tulisi käsitellä luontaisena osana yrityksen strategista ja operatiivista toimintaa sekä sen jälkeen perehtyisivät opettajankoulutuksessa ympäristökasvatuksen tavoitteita tukeviin pedagogisiin ratkaisuihin. Kauppakorkeakouluissa ympäristöasioihin liittyvät kurssit ovat kuitenkin toistaiseksi vapaaehtoisia, eikä ympä- 
ristökasvatusta ole systemaattisesti integroitu myöskään eri oppiaineiden sisään. Lisäksi ammatillisissa opettajakorkeakouluissakin ympäristökasvatuksen näkökulma hakee vielä paikkaansa.

Ympäristökasvatuksen kehittämisen kannalta tutkimuksen puutteena voidaan pitää sitä, että siinä ei analysoitu ammattikorkeakouluissa toteutettavien ympäristökasvatukseen liittyvien erillisten kurssien sisältöä. Tutkimus ei siten anna vastausta siihen, miten kyseisten kurssien sisällä toteutuu ympäristökasvatuksen holistinen oppimiskäsitys. Tämä puute on kuitenkin mielestäni oman erillisen tutkimuksen arvoinen kysymys.

\section{Lähteet}

ALASUUTARI, P. (1988). Erinomaista rakas Watson. Johdatus yhteiskuntatutkimukseen. TammerPaino Oy. Tampere.

AUTIO, T. \& Nikander,E \& Silfverberg, H. (1998). Koulutuspolitiikka ja aineenopettajakoulutus. Aikuiskasvatus, 4; 303-312.

BALL, S. (1984). Beachside Reconsidered: Reflections on a Methodological Apprenticeship. Teoksessa: Burges, R. The Research Process in Educational Settings: Ten Case Studies. Lewes: The Falmer Press. Ss. 69-96.

BALLANTYNE, R.R. \& Packer, J.M. (1996). Teaching and Learning in Environmental Education: Developing Environmental Conceptions. The Journal of Environmental Education, Vol. 27, No. 2: $25-32$.

BARNES, A. \& Ferry, J.K. (1992). Creating a nice for the environment in the business school curriculum. Business Horizons, March-April: 3-8.

BECKER, T. (1997). The Greening of a Business School. The Journal of Environmental Education, Vol 28, No. 3: 5-9.

BERINGER, K. \& Tapio, P. \& Willamo, R. (1999). Ympäristönsuojelun perusteet. Gaudeamus. TammerPaino Oy. Tampere.

BLACKMAN, D. A. \& Fleming, T. G. (1998a). Environmental Education: Where Does it Fit in DecisionMaking? Teoksessa: Park, P.D. \& Blackman, D. A. \& Chong, G. (toim.). Environmental Education and Training. Ss. 82-92.

BLACKMAN, D. A. \& Fleming, T.G. (1998b). Why and How Organisations Provide Employees with Environmental Education? Teoksessa: Park, P. D. \& Blackman, D. A. \& Chong, G.(toim.). Environmental Education and Training. Ss. 101-113.

BRAGD, A. \& Bridge, G. \& den Hond F. \& Jose, P.D. (1998). Beyond Greening: New Dialogue and New Approaches for Developing Sustainability. Business Strategy and the Environment, 7:179-192.

CRAMER, J. (1998). Environmental management: from fit to stretch. Business strategy and the environment, 7: 162-172.

GOETZ, J.P. \& LeCompte, M.D. (1984). Ethnography and Qualitative Design in Educational Research. London: Academic Press, Inc.

GREENALL, A. (1986). Searching for a meaning. What is environmental education? Geographical Education, 5/2:9-12.

HAKKARAINEN, K. \& Lonka, K. \& Lipponen, L. (1999). Tutkiva oppiminen. Älykkään toiminnan rajat ja niiden ylittäminen. WSOY: Helsinki.

Hallituksen kestävän kehityksen ohjelma. Valtioneuvoston periaatepäätös ekologisen kestävyyden edistämisestä. 1998. Ympäristöministeriö: Helsinki.

HART, S.L. 1997. Strategies for a Sustainable World. Harward Business Review, January-February: 6776.

HYNNINEN, P. (1998). Development of Environmental Education: A Theoretical and Methodological Model for a Sustainable Way of Life. Teoksessa: Åhlberg, M. \& Leal, W.F. (toim.). Environmental Education for Sustainability: Good Environment, Good Life. Peter Lang GmgH. Germany. Ss. $287-295$.

HYYTIÄINEN, J. \& Hämeenoja, E. \& Hänninen, T. \& Leinonen, E. \& Tenhunen, R. (1999). Kestävä kehitys oppilaitoksissa - ekoauditoinnin opas. Opetushallitus.

IUCN. (1980). World Conservation Satrategy. Gland Swizerland: IUCN, WWF, UNEP.

JOUTSENVIRTA, M. (1998). Ympäristönsuojelijat uhka vai mahdollisuus yrityksille? IBS- Raporttisarjat 1998, Eurooppa raportti, 5. Www.stat.fi/ ibs, ss. 49-54.

JÄRVELÄ, S. (1997). Tietokoneavusteinen intentionaalinen oppimisympäristö osana kemian tutkivaa oppimisprojektia. Teoksessa: Lehtinen, E. Verkkopedagogiikka. Edita. Ss. 85-100.

KAUPPI, A. (1998). Uudistava oppiminen, koulutus ja työn kehittäminen. Hankeperustaisen oppisopimuskoulutuksen loppuraportti. Opetushallitus. Tutkimussarja 2.

LINDE, G. (1993). On Curriculum Transformation: Explaining Selection of Content in Teaching. Doctoral Dissertation at Uppsala University.

LONKA, K \& Hakkarainen, K. (2000). Oppiminen vuonna 2020. Psykologia 2/2000, 135-142.

LONKA, K. \& Hakkarainen, K. (2000). Oppiminen vuonna 2020. Psykologia 2/2000. Ss. 135-142.

LOVIO, R. (1995). Yritykset ja Ympäristö: Ongelmien ratkaisuista uusiin ongelmiin. Teoksessa: Massa, I. \& Rahkonen, O. (toim.). Riskiyhteiskunnan talous. Hakapaino Oy. Helsinki. Ss. 143-159.

LOVIO, R. (1998). Ympäristöjohtaminen on osa liiketoimintaa. IBS- Raporttisarjat, Eurooppa raportti, 5. www.stat.fi/ibs, ss. 27-30.

MALINEN, P. (1985). Opetussuunnitelmat nykyajan koulutuksessa. Otava. Helsinki.

MRAZEK, R. (1993). Through which looking glass? Defining Environmental Education Research. Alternative Paradigms in Environmental Education Research. Troy, Ohio. North American Association of Environmental Education.

OJANEN, S. \& Rikkinen, H. (1995). Johdanto ja artikkelien esittely. Teoksessa: Opettaja ympäristökasvattajana. Opetus 2000. WSOY. Juva.

PALMER, J. (1998). Environmental Education in the $21^{\text {st }}$ Century. Theory, practice, progress and 
promise. Routledge. London.

RAJANEN, J. (1998). Ammattikorkeakoulun ympäristökasvatuksen lähtökohtia. Ympäristöön liittyvän huolestuneisuuden ja moraaliajattelun ulottuvuudet ja niihin yhteydessä olevat tekijät Kemi-Tornion ammattikorkeakoulun opiskelijoilla. Kasvatustieteen lisensiaattitutkielma. Kasvatustieteiden tiedekunta. Lapin yliopisto.

RAUMOLIN, J. (2000). Towards Sustainable Education in Finland. A Proposal for Criteria and Indicators for Sustainable Education. Report to the SUSDEED Project. University of Helsinki. Institute of Development Studies.

RAUSTE-VON WRIGHT, M. (1994). Opetussuunnitelma ja oppimiskäsitys. Teoksessa: Elinikäinen oppiminen. Vapaan sivistystyön 35. Vuosikirja. Kansanvalistusseura ja Aikuiskasvatuksen tutkimusseura.

ROHWEDER, L. (2001). Ympäristökasvatus ammattikorkeakoulussa. Opetussuunnitelmateoreettisen mallin kehittäminen liiketalouden koulutukseen. Helsinki School of Economics and Business Administration. Acta Universitatis Oeconomicae Helsingiensis. A-190.

ROPO, E. (1994). Opetussuunnitelmat ja elinikäinen oppiminen. Teoksessa: Elinikäinen oppiminen. Vapaan sivistystyön 35. Vuosikirja. Kansanvalistusseura ja Aikuiskasvatuksen Tutkimusseura.

SHERMAN, R \& Webb, R. (1988). Qualitative Research in Education: Focus and Methods. Lewes: Falmer.

SINDING, K. \& Ulhoi, J.P. \& Madsen, H. (1997). Training and Education of Environmental Managers. Working Paper 97-1. Department of Organization and Management. Faculty of Business Administration. Denmark.

SIPILÄ, M. 1998. Uraohjuksia ympäristöasioihin. Ekonomi 3/1998: 16-20.

SMITH, D. \& Deborath, H. \& McCloskey, J. (1994). Greening the business school. Management learning, vol 25/3: 475-488.

STAP, W.B. (1969). The concept of environmental education. Journal of Environmental Education 1(1):30-31.

SYRJÄLÄ, L. \& Ahonen, S. \& Saari, S. (1994). Laadullisen tutkimuksen työtapoja. Kirjapaino Westpoint. Rauma.

TELLA, S. (1994). Uusi tieto- ja viestintätekniikka avoimen oppimisympäristön kehittäjänä. Osa 1. Helsingin yliopisto. Tutkimuksia 124. Helsinki.

TILBURY, D. \& Walford, R. (1996). Grounded Theory: Defying the Dominant Paradigm in Environmental Education Research. Teoksessa: Michael W. (toim.) Understanding Geographical and Environmental Education. The Role of Research. Cassell. London.

TURTIAINEN, M. (1991). Institutionaalinen ympäristötaloustiede. Teoksessa: Massa, I. \& Sairanen, R. (toim.). Ympäristökysymys - Ympäristöuhkien haaste yhteiskunnalle. Ss. 142-161.

ULHOI, J. P. \& Madsen, H. (1995). The Greening of European Management Education. GMI 10/April: $85-95$.

UNCED (1992). United Nations Conference on Environment and Development. Rio de Janeiro 3.14.6.1992. Agenda 21. Ministry of Foreign Af- fairs. Political Department. Division of International Environmental Affairs.

WAHLSTRÖM, R. (1993).Ympäristölukutaitoisuuteen taloustieteen koulutuksessa. Kansantaloudellinen aikakauskirja, 89. Vsk. -3/: 357-365.

VON WRIGHT, J. (1993). Oppimiskäsitysten historiaa ja pedagogisia seurauksia. Aikuiset ja koulutus 7. Opetushallitus. Helsinki.

\section{Opiskelijat sitoutuvat jos ovat mukana suunnittelussa}

Yliopisto-opiskelijat on syytä ottaa mukaan suunittelemaan ympäristöopetusta ja kehittämään sitä aktiivisesti jatkuvan reflektoinnin avulla, jos mieli sitouttaa heidät opiskeluun saada heidät tuntemaan subjekteiksi opetuksen kohteena olemisen sijasta. Tähän mm. päätyi Pirjo Äänismaa väitöstutkimuksessaan "Ympäristökasvatusta kehittämässä kotitalousopettajien opetuksessa: Kestävän kehityksen mukaisen asumisen ajattelu- ja toimintamallin kehittämistä toimintatutkimuksen avulla vuosina 1995-1998". Äänismaa väitteli Joensuun yliopiston kasvatustieteellisessä tiedekunnassa Savonlinnassa 6. kesäkuuta. Hänen vastaväittäjänään oli professori Terttu TuomiGröhn Helsingistä.

Pirjo Äänismaa tarkasteli väitöskirjassaan ympäristökasvatushanketta, joka toteutettiin Savonlinnan opettajankoulutuslaitoksen kotitalousopettajien koulutuksessa. Tutkimus- ja kehittämishankkeen tavoitteena oli kehittää kotitaloustieteen asumisen opetus-, opiskelu- ja oppimisprosessia sekä kestävän kehityksen mukaisen asumisen ajattelu- ja toimintamallia.

Tutkimuksen kohteena olleessa ympäristökasvatushankkeessa opiskelijat oppivat toimimaan hyvän ympäristön puolesta sosiaalisessa vuorovaikutuksessa toisten kanssa. Osallistujat alkoivat arvioida omaa toimintaansa ja siihen vaikuttavia tekijöitä kestävän kehityksen kannalta sekä kotitalousopettajien mahdollisuuksia ympäristökasvatuksessa.

Pirjo Äänismaan väitöskirjasta kerrotaan lisää Aikuiskasvatuksen nettisivulla www.kvs.fi $>$ Aikuiskasvatusjulkaisut $>$ Aikuiskasvastus $>$ Tärppejä nettilukijalle. 